\title{
Candidimonas nitroreducens gen. nov., sp. nov. and Candidimonas humi sp. nov., isolated from sewage sludge compost
}

Correspondence
Célia M. Manaia
cmmanaia@esb.ucp.pt

\author{
Ivone Vaz-Moreira, ${ }^{1,2}$ Vânia Figueira, ${ }^{1}$ Ana R. Lopes, ${ }^{2}$ Evie De Brandt, ${ }^{3}$ \\ Peter Vandamme, ${ }^{3}$ Olga C. Nunes ${ }^{2}$ and Célia M. Manaia ${ }^{1}$ \\ ${ }^{1}$ CBOF - Escola Superior de Biotecnologia, Universidade Católica Portuguesa, 4200-072 Porto, \\ Portugal \\ ${ }^{2}$ LEPAE - Departamento de Engenharia Química, Faculdade de Engenharia, Universidade do Porto, \\ 4200-465 Porto, Portugal \\ ${ }^{3}$ Laboratorium voor Microbiologie, Vakgroep Biochemie en Microbiologie, Universiteit Gent, Gent, \\ Belgium
}

Two bacterial strains, designated $\mathrm{SC}-089^{\mathrm{T}}$ and $\mathrm{SC}-092^{\mathrm{T}}$, were isolated from sewage sludge compost during a study on the diversity of culturable bacteria from final composts (Vaz-Moreira et al., 2008). As discussed below, these isolates shared about $99 \%$ 16S rRNA gene sequence similarity and were observed to be members of the family Alcaligenaceae. Among the closest neighbours of strains SC- $089^{\mathrm{T}}$ and $\mathrm{SC}-092^{\mathrm{T}}$ were members of the genera Parapusillimonas, Achromobacter, Bordetella, Castellaniella, Pigmentiphaga and Pusillimonas, with Parapusillimonas granuli, Pigmentiphaga kullae and Bordetella petrii as nearest neighbours. To test the hypothesis that strains SC $-089^{\mathrm{T}}$ and SC- $092^{\mathrm{T}}$ could be members of a new genus, these strains were compared with the type strains of the type species of the above genera, as well as with the type

The GenBank/EMBL/DDBJ accession numbers for the 16S rRNA gene

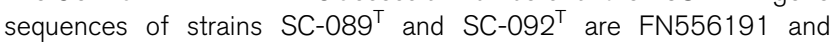
FN556192, respectively. strain of the closest related species within each genus. The only exception was made for the the type species Bordetella pertussis, which, given its potential hazardous nature, was substituted by Bordetella bronchiseptica, with which the type strains studied here shared identical $16 \mathrm{~S}$ rRNA gene sequences. Thus, strains $\mathrm{SC}-089^{\mathrm{T}}$ and $\mathrm{SC}-092^{\mathrm{T}}$ were compared with Parapusillimonas granuli LMG $24012^{\mathrm{T}}$, Pigmentiphaga kullae CCUG $47266^{\mathrm{T}}$, B. petrii CCUG $43448^{\mathrm{T}}$, B. bronchiseptica LMG $1232^{\mathrm{T}}$, Achromobacter xylosoxidans LMG $1863^{\mathrm{T}}$, Achromobacter denitrificans LMG $1231^{\mathrm{T}}$, Castellaniella defragrans $\mathrm{LMG} 18538^{\mathrm{T}}$, Castellaniella denitrificans CCUG $39541^{\mathrm{T}}$ and Pusillimonas noertemannii DSM $10065^{\mathrm{T}}$, which were supplied by the respective culture collections. Unless stated otherwise, the organisms were cultivated on plate count agar (PCA; Pronadisa), incubated at $30{ }^{\circ} \mathrm{C}$ and stored at $-80{ }^{\circ} \mathrm{C}$ in nutritive broth with $15 \%$ (v/v) glycerol. Colony and cell morphology, Gram staining, cytochrome $c$ oxidase and catalase tests, and motility were analysed based on the 
methodologies of Murray et al. (1994) and Smibert \& Krieg (1994). Additional phenotypic characterization was based on the methods described previously (Vaz-Moreira et al., 2007). Biochemical and nutritional tests were performed by using the commercial kits API 20E, API 20NE, API ZYM and API ID 32GN (bioMérieux) following the manufacturer's instructions. The Voges-Proskauer test was assayed in methyl red and Voges-Proskauer medium (Oxoid), incubated at $30{ }^{\circ} \mathrm{C}$ for $48 \mathrm{~h}$. Simmons citrate was tested on Simmons citrate agar (Pronadisa) incubated for 7 days at $30{ }^{\circ} \mathrm{C}$. Urease activity was assayed as described by Smibert \& Krieg (1994).

After $48 \mathrm{~h}$ incubation at $30{ }^{\circ} \mathrm{C}$ on PCA, strains SC- $089^{\mathrm{T}}$ and SC- $092^{\mathrm{T}}$ formed convex white colonies. Growth was optimal at $30{ }^{\circ} \mathrm{C}$, at $\mathrm{pH} 7$ and in the presence of $1 \%(\mathrm{w} / \mathrm{v})$ $\mathrm{NaCl}$ and was supported by different amino acids and organic acids. The nucleotide sequence of the 16S rRNA gene was determined after PCR amplification of total DNA extracts as described previously (Ferreira da Silva et al., 2007). The 16S rRNA gene sequence was compared with others available in GenBank databases by using the FASTA package from EMBL-EBI. Phylogenetic analysis was conducted using the BioNumerics software package (version 6.0; Applied Maths). Sequence similarity was estimated based on the model of Jukes \& Cantor (1969) and the dendrogram was created with the neighbourjoining method. The maximum-parsimony and maximumlikelihood methods were used to assess tree stability. Non-homologous and ambiguous nucleotide positions were excluded from the calculations. Strains $\mathrm{SC}-089^{\mathrm{T}}$ and SC- $092^{\mathrm{T}}$ shared $99.1 \% 16 \mathrm{~S}$ rRNA gene sequence similarity, but shared lower levels with Parapusillimonas granuli LMG
$24012^{\mathrm{T}}$ (97.8 and $97.4 \%$, respectively), Pigmentiphaga kullae CCUG $47266^{\mathrm{T}}$ (97.1 and $\left.97.3 \%\right)$ and B. petrii CCUG $43448^{\mathrm{T}}$ (both $96.9 \%$ ), which represented their nearest phylogenetic neighbours (Fig. 1). Either both strains $\mathrm{SC}-089^{\mathrm{T}}$ and $\mathrm{SC}-092^{\mathrm{T}}$ or one of them showed lower $16 \mathrm{~S}$ rRNA gene sequence similarity to members of other related species: respectively 97.0 and $96.6 \%$ with $A$. xylosoxidans LMG $1863^{\mathrm{T}}, 96.9$ and $96.8 \%$ with $A$. denitrificans LMG $1231^{\mathrm{T}}, 96.3$ and $95.8 \%$ with $B$. bronchiseptica LMG $1232^{\mathrm{T}}, 96.5$ and $96.0 \%$ with $C$. defragrans LMG $18538^{\mathrm{T}}$, 96.6 and $96.1 \%$ with $C$. denitrificans LMG $25533^{\mathrm{T}}$, and 96.2 and $95.9 \%$ with Pusillimonas noertemannii DSM $10065^{\mathrm{T}}$. The two novel strains represented a distinct line of descent in the family Alcaligenaceae and their phylogenetic position was supported by a high bootstrap value and by the different treeing algorithms used.

DNA-DNA hybridizations were performed between strains SC- $089^{\mathrm{T}}$ and $\mathrm{SC}-092^{\mathrm{T}}$, and with Pigmentiphaga kullae CCUG $47266^{\mathrm{T}}$ and Parapusillimonas granuli LMG $24012^{\mathrm{T}}$. DNA was extracted from $0.25-0.5 \mathrm{~g}$ (wet weight) cells as described by Pitcher et al. (1989). DNA-DNA hybridizations were performed with photobiotin-labelled probes in microplate wells (Ezaki et al., 1989), by using an HTS7000 Bio Assay Reader (Perkin Elmer) for fluorescence measurements. The hybridization temperature was $47{ }^{\circ} \mathrm{C}$. Reciprocal experiments were performed for every pair of strains and levels of relatedness differed by between 1 and $7 \%$. The level of DNA-DNA relatedness between strains SC- $089^{\mathrm{T}}$ and SC- $092^{\mathrm{T}}$ was $41 \%$; levels of relatedness with the other type strains investigated were $30 \%$ or lower (data not shown).

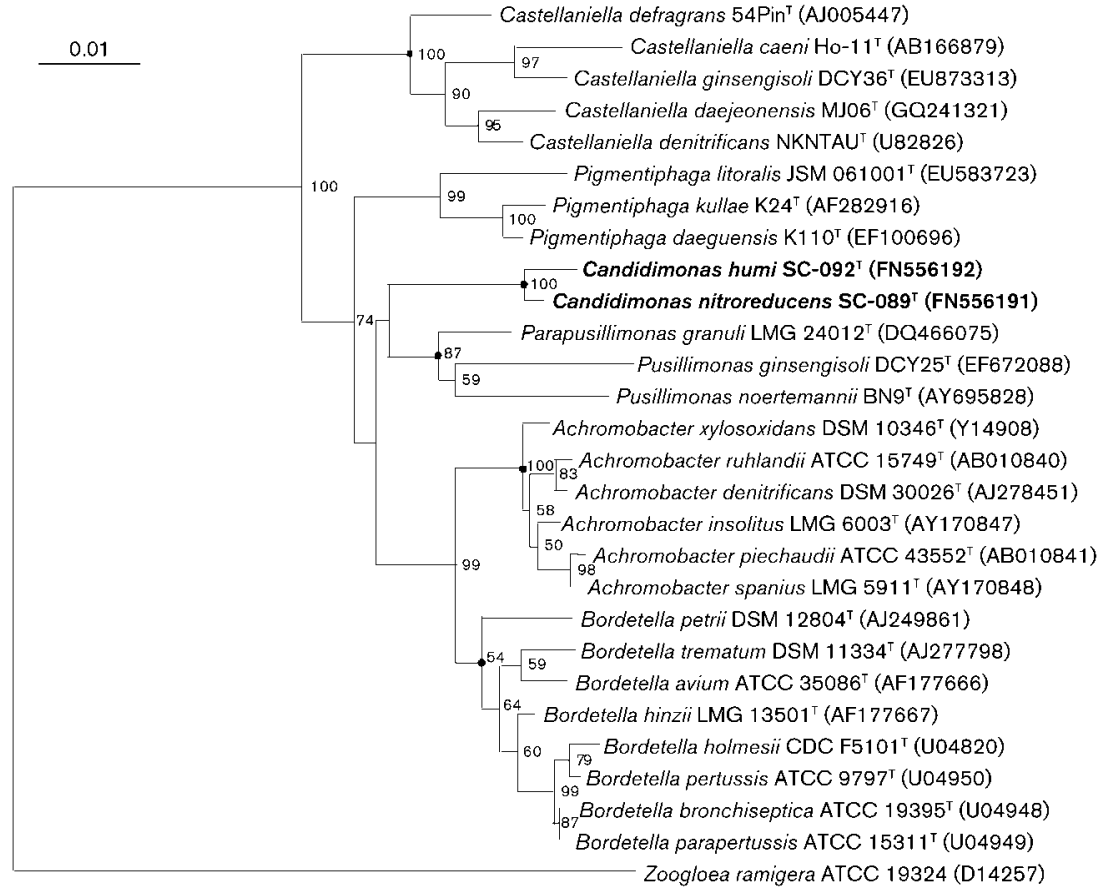

Fig. 1. Phylogenetic tree derived from 16S rRNA gene sequence analysis, showing the relationship of strains $\mathrm{SC}-089^{\top}$ and SC-092 ${ }^{\top}$ with members of the family A/caligenaceae. The tree was generated by the neighbourjoining method and Zoogloea ramigera ATCC 19324 was used as outgroup. Bootstrap values, generated from 1000 resamplings, at or above $50 \%$ are indicated at branch points. Closed circles indicate branches also recovered by the maximum-likelihood method. Bar, 1 substitution per 100 nucleotide positions. 
Fatty acid methyl esters were analysed after an incubation period of 24 or $48 \mathrm{~h}$ (C. defragrans LMG $18538^{\mathrm{T}}$ and Pusillimonas noertemanii DSM $10065^{\mathrm{T}}$ ) at $28^{\circ} \mathrm{C}$. A loopful of well-grown cells was harvested and fatty acid methyl esters were prepared as described previously (Vandamme et al., 1992), and separated and identified by using the Sherlock Microbial Identification System (version 3.1; MIDI Inc.). The polar lipid composition was determined as described previously (Manaia et al., 2004) (Fig. 2).

Determination of the $\mathrm{G}+\mathrm{C}$ content of the genomic DNA and of the respiratory quinones was performed as described previously (Vaz-Moreira et al., 2007) by using, respectively, the methods of Mesbah et al. (1989) and Tindall (1989). The respiratory quinone was ubiquinone 8 . The DNA G + C content of strains SC $-089^{\mathrm{T}}$ and SC- $092^{\mathrm{T}}$ was 64 and $65 \mathrm{~mol} \%$, respectively. These chemotaxonomic traits confirm the affiliation of strains SC- $089^{\mathrm{T}}$ and SC$092^{\mathrm{T}}$ to the family Alcaligenaceae (Vancanneyt et al., 1995; Blümel et al., 2001; von Wintzingerode et al., 2001; Busse \&
Auling, 2005; Stolz et al., 2005), although the unique phylogenetic position suggests that they are most appropriately allocated to a new genus.

At the phenotypic level, strains SC- $089^{\mathrm{T}}$ and $\mathrm{SC}-092^{\mathrm{T}}$ could also be distinguished from the type strains of the type species of related genera as well as from the type strains of the most closely related species (Table 1). For example, strains SC- $089^{\mathrm{T}}$ and $\mathrm{SC}-092^{\mathrm{T}}$ could be distinguished from the members of the other genera examined in this study based on the absence of motility (present in members of the genera Achromobacter, Pigmentiphaga, Castellaniella, Pusillimonas and Parapusillimonas), inability to assimilate L-alanine (observed in members of the genera Achromobacter, Bordetella, Castellaniella and Parapusillimonas) and L-proline (also absent in members of the genera Pigmentiphaga and Pusillimonas), and the ability to assimilate 3-hydroxybenzoic acid (absent in members of the genus Bordetella) and several other organic acids and sugars. These differential phenotypic characteristics, along with their unique phylogenetic position, suggest that
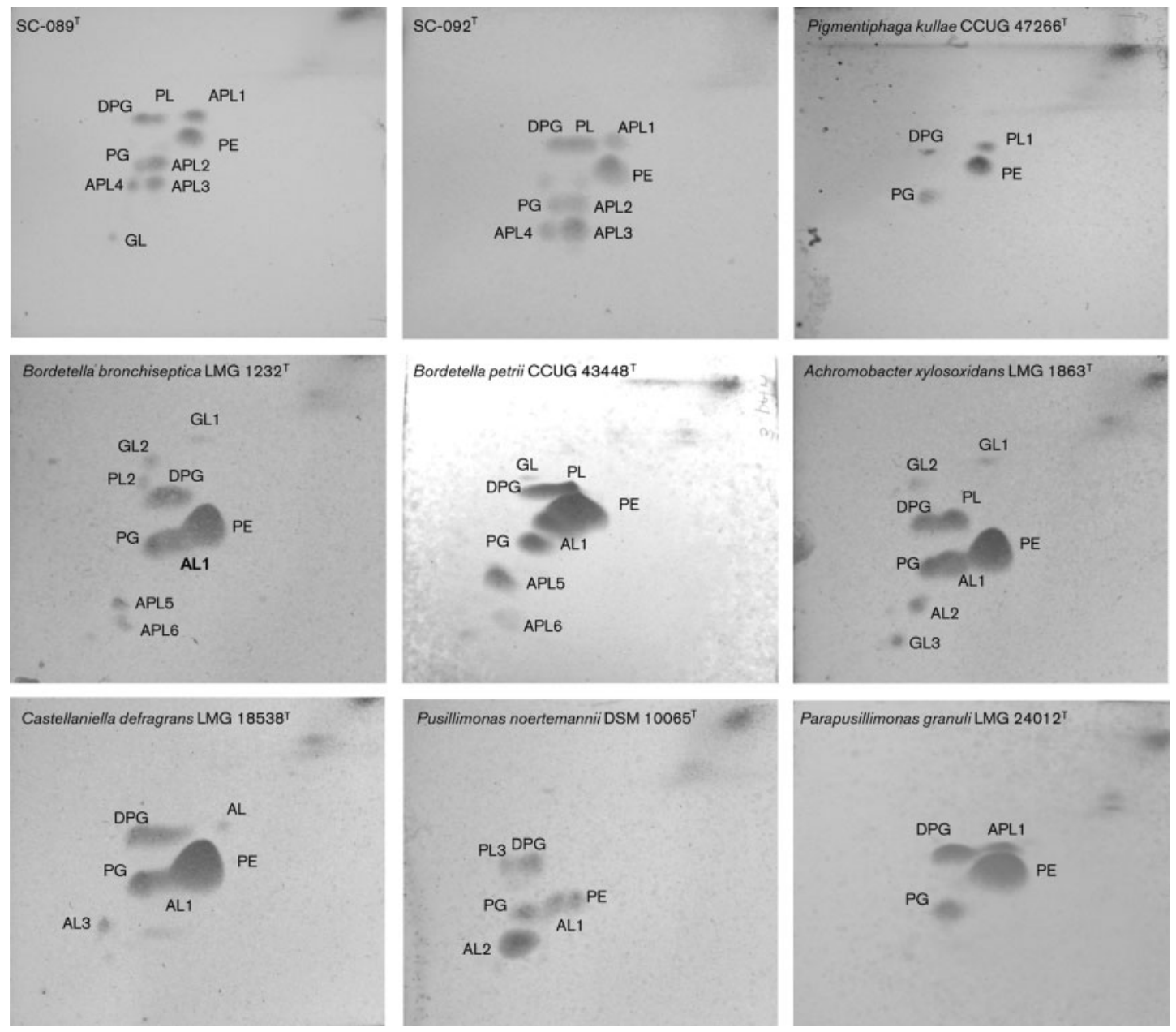

Fig. 2. Polar lipid patterns of strains $\mathrm{SC}-089^{\top}$ and $\mathrm{SC}-092^{\top}$ and related members of the family Alcaligenaceae. PE, Phosphatidylethanolamine; PG, phosphatidylglycerol; DPG, diphosphatidylglycerol; PL, APL, GL and AL, respectively, unidentified phospholipid, aminophospholipid, glycolipid and aminolipid. 
Table 1. Differential characteristics between strains SC- $089^{\top}$ and $S C-092^{\top}$ and the type strains of closely related species

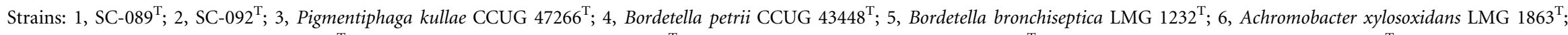

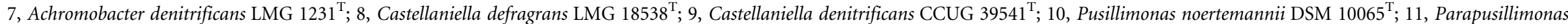
granuli LMG $24012^{\mathrm{T}}$. Data are from the present study except where indicated otherwise. W, Weakly positive; NA, not available.

\begin{tabular}{|c|c|c|c|c|c|c|c|c|c|c|c|}
\hline Characteristic & 1 & 2 & 3 & 4 & 5 & 6 & 7 & 8 & 9 & 10 & 11 \\
\hline Motility & - & - & $+{ }^{\star a}$ & $-{ }^{b}$ & $+{ }^{c}$ & $+{ }^{d}$ & $+{ }^{d}$ & $+{ }^{e}$ & $+^{e}$ & $+^{f}$ & $+^{g}$ \\
\hline Simmons citrate & - & - & - & + & - & + & - & + & - & - & - \\
\hline Urease & - & - & - & - & + & - & - & - & - & - & + \\
\hline \multicolumn{12}{|l|}{ Assimilation of: } \\
\hline Glucose & - & - & + & - & - & + & - & - & - & $\mathrm{w}$ & + \\
\hline D-Mannose & - & - & + & - & - & $\mathrm{w}$ & - & - & - & - & - \\
\hline L-Alanine & - & - & - & + & + & + & + & + & + & - & + \\
\hline L-Proline & - & - & - & + & - & + & + & + & + & - & + \\
\hline L-Serine & - & - & - & + & - & + & - & + & - & - & + \\
\hline Adipate & + & + & + & + & + & + & + & - & - & - & + \\
\hline Caprate & - & - & - & - & $\mathrm{w}$ & + & $\mathrm{w}$ & $\mathrm{w}$ & $\mathrm{w}$ & - & - \\
\hline $\begin{array}{l}\text { 3-Hydroxybenzoic } \\
\text { acid }\end{array}$ & + & + & + & - & - & - & + & + & + & + & + \\
\hline Itaconic acid & + & + & $\mathrm{w}$ & + & + & + & + & - & + & - & + \\
\hline Lactic acid & + & + & - & + & + & + & + & + & + & - & + \\
\hline Phenyl acetate & + & + & - & - & + & + & + & $\mathrm{w}$ & - & - & + \\
\hline Propionic acid & + & + & - & + & + & + & + & + & + & + & + \\
\hline Sodium acetate & + & + & - & + & + & + & + & + & + & + & + \\
\hline Suberic acid & - & - & - & + & - & + & + & - & - & - & - \\
\hline Valeric acid & + & + & - & + & + & + & + & + & + & - & + \\
\hline $\begin{array}{l}\text { DNA G }+\mathrm{C} \\
\text { content }(\mathrm{mol} \%)\end{array}$ & 63.9 & 65.2 & $68.5^{a}$ & $63.8^{b}$ & $67-69^{c} \dagger$ & $66.9-69.8^{d_{\dagger}}$ & $63.9-68.9^{d_{\dagger}}$ & $66.9^{h} \dagger$ & NA & $61.8^{f_{\dagger}}$ & $67.9^{g}$ \\
\hline $\begin{array}{l}\text { Source of isolation } \\
\text { of the type strain }\end{array}$ & $\begin{array}{l}\text { Sewage sludge } \\
\text { compost }\end{array}$ & $\begin{array}{l}\text { Sewage } \\
\text { sludge } \\
\text { compost }\end{array}$ & Soil & $\begin{array}{l}\text { Dechlorinating } \\
\text { bioreactor/ } \\
\text { clinical sources }\end{array}$ & $\begin{array}{c}\text { Respiratory } \\
\text { tract of } \\
\text { animals }\end{array}$ & $\begin{array}{l}\text { Mostly } \\
\text { clinical } \\
\text { isolates }\end{array}$ & $\begin{array}{l}\text { Soil/clinical } \\
\text { isolates }\end{array}$ & $\begin{array}{c}\text { Alkenoic } \\
\text { monoterpenes }\end{array}$ & $\begin{array}{c}\text { Anaerobic } \\
\text { sludge digestor }\end{array}$ & Water & $\begin{array}{c}\text { Anaerobic sludge } \\
\text { blanket reactor }\end{array}$ \\
\hline
\end{tabular}

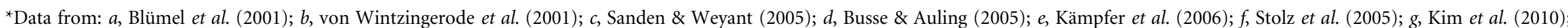
h, Foss et al. (1998).

$\dagger$ Determined by $T_{\mathrm{m}}$. 
strains SC- $089^{\mathrm{T}}$ and $\mathrm{SC}-092^{\mathrm{T}}$ should be most appropriately allocated to a new genus.

Cellular fatty acid composition also allowed strains SC- $089^{\mathrm{T}}$ and SC- $092^{\mathrm{T}}$ to be differentiated from the type strains of related species (Table 2). The predominant fatty acids common to strains $\mathrm{SC}-089^{\mathrm{T}}$ and $\mathrm{SC}-092^{\mathrm{T}}$ were summed feature $2\left(\mathrm{C}_{14: 0} 3-\mathrm{OH}\right.$ and/or iso- $\left.\mathrm{C}_{16: 1} \mathrm{I}\right), \mathrm{C}_{16: 0}$ and $\mathrm{C}_{18: 1} \omega 7 c$. The two organisms differed in the abundance of cyclo- $\mathrm{C}_{17: 0}$ and summed feature $3\left(\mathrm{C}_{16: 1} \omega 7 c\right.$ and/or iso$\left.\mathrm{C}_{15: 0} 2-\mathrm{OH}\right)$ and in the presence of iso- $\mathrm{C}_{17: 0} 3-\mathrm{OH}$. The pattern of fatty acids of strains SC- $089^{\mathrm{T}}$ and $\mathrm{SC}-092^{\mathrm{T}}$ was different from those of the strains examined in at least two components that differed by $>5 \%$. The presence of $\mathrm{C}_{16: 0} 2$ $\mathrm{OH}$ and $\mathrm{C}_{16: 1} 2-\mathrm{OH}$ was also distinctive, these components only being present in strains SC- $089^{\mathrm{T}}$ and $\mathrm{SC}-092^{\mathrm{T}}$ and in Pigmentiphaga kullae LMG $21665^{\mathrm{T}}$. However, $\mathrm{C}_{12: 0} 2-\mathrm{OH}$ was not detected in Pigmentiphaga kullae LMG $21665^{\mathrm{T}}$.

Analysis of the pattern of polar lipids also distinguished strains SC- $089^{\mathrm{T}}$ and SC- $092^{\mathrm{T}}$ from members of the closely related genera (Fig. 2). Although phosphatidylethanolamine, phosphatidylglycerol and diphosphatidylglycerol were present in members of the other genera, their proportions, along with the presence/absence of unknown phospholipids and aminolipids, were distinctive characteristics among the taxa under study. Pigmentiphaga kullae CCUG $47266^{\mathrm{T}}$ presented the most differentiated polar lipid pattern, with a low proportion of diphosphatidylglycerol and the absence of most of the unknown phospholipids and amino(phospho)lipids otherwise noted. The absence of unknown aminolipid AL2 permitted us to distinguish between strains SC- $089^{\mathrm{T}}$ and SC- $092^{\mathrm{T}}$ and members of other related genera, as it constitutes a major lipid in Pusillimonas noertemannii DSM $10065^{\mathrm{T}}$, and is present in low proportions in $A$. xylosoxidans LMG $1863^{\mathrm{T}}$. Additionally, the exclusive presence of unknown aminophospholipids APL2, APL3 and APL4 in strains $\mathrm{SC}-089^{\mathrm{T}}$ and $\mathrm{SC}-092^{\mathrm{T}}$ contributed to distinguishing these organisms from related genera (Table 3 ).

Distinction of genera of the family Alcaligenaceae on the basis of phenotypic characteristics is not possible, as demonstrated in previous studies, namely for the descriptions of the genera Pigmentiphaga, Pusillimonas and Parapusillimonas (Blümel et al., 2001; Stolz et al., 2005; Kim et al., 2010), which do not refer to any distinctive phenotypic trait. In fact, a literature review of studies of the phenotypic description of members of the genera Achromobacter, Bordetella, Castellaniella, Pusillimonas, Pigmentiphaga and Parapusillimonas shows that, among a group of $>50$ tests of carbon-source assimilation, enzyme production/activity and other physiological traits, these characteristics are variable within each genus and/or are not differential among these genera (Kersters et al., 1984; Foss et al., 1998; Vandamme

Table 2. Fatty acid composition of strains SC- $089^{\top}$ and $\mathrm{SC}-092^{\top}$ and the type strains of closely related species

Strains: 1, SC-089 ${ }^{\mathrm{T}} ; 2$, SC- $092^{\mathrm{T}} ; 3$, Pigmentiphaga kullae LMG $21665^{\mathrm{T}} ; 4$, Bordetella bronchiseptica LMG $1232^{\mathrm{T}} ; 5$, Bordetella petrii CCUG $43448^{\mathrm{T}}$; 6, Achromobacter xylosoxidans LMG $1863^{\mathrm{T}} ; 7$, Achromobacter denitrificans LMG $1231^{\mathrm{T}}$; 8 , Castellaniella defragrans LMG $18538^{\mathrm{T}}$; 9 , Castellaniella denitrificans CCUG $39541^{\mathrm{T}} ; 10$, Pusillimonas noertemannii DSM $10065^{\mathrm{T}} ; 11$, Parapusillimonas granuli LMG $24012^{\mathrm{T}}$. Those fatty acids for which the amount for all taxa was $<1 \%$ are not included. Therefore, the percentages may not add up to $100 \%$. tr, Trace amount $(<1 \%)$; ND, not detected.

\begin{tabular}{|c|c|c|c|c|c|c|c|c|c|c|c|}
\hline Fatty acid & $1^{*}$ & 2 & $3 \dagger$ & 4 & 5 & 6 & 7 & 8 & 9 & $10 \ddagger$ & $11 \S$ \\
\hline $\mathrm{C}_{10: 0} 2-\mathrm{OH}$ & 1.7 & $\operatorname{tr}$ & ND & $\mathrm{ND}$ & $\mathrm{ND}$ & $\mathrm{ND}$ & ND & ND & $\mathrm{ND}$ & $\mathrm{ND}$ & ND \\
\hline $\mathrm{C}_{12: 0}$ & $\operatorname{tr}$ & $\operatorname{tr}$ & $\mathrm{ND}$ & $\operatorname{tr}$ & $\operatorname{tr}$ & $\operatorname{tr}$ & $\operatorname{tr}$ & 4.8 & 6.5 & 8.2 & $\mathrm{ND}$ \\
\hline $\mathrm{C}_{14: 0}$ & $\mathrm{ND}$ & $\mathrm{ND}$ & $\mathrm{ND}$ & 4.8 & 5.4 & 1.7 & 5.1 & $\operatorname{tr}$ & $\operatorname{tr}$ & $\mathrm{ND}$ & $\mathrm{ND}$ \\
\hline $\mathrm{C}_{14: 0} 2-\mathrm{OH}$ & $\mathrm{ND}$ & $\mathrm{ND}$ & 4.6 & $\mathrm{ND}$ & $\operatorname{tr}$ & 3.4 & $\mathrm{ND}$ & $\mathrm{ND}$ & $\mathrm{ND}$ & $\mathrm{ND}$ & $\mathrm{ND}$ \\
\hline SF2II & 20.4 & 16.7 & 6.8 & 7.6 & 8.4 & 10.6 & 10.7 & 6.4 & 8.6 & 22.7 & 7.4 \\
\hline$C_{16: 0}$ & 25.9 & 25.1 & 28.4 & 34.1 & 32.2 & 33.8 & 30.2 & 30.4 & 31.6 & 10.3 & 33.2 \\
\hline $\mathrm{C}_{17: 0}$ cyclo & 17.9 & 6.2 & 17.1 & 10.6 & 16.0 & 19.6 & 15.2 & 15.8 & 13.0 & 18.9 & 18.2 \\
\hline $\mathrm{C}_{16: 1} 2-\mathrm{OH}$ & 1.5 & 3.6 & 1.1 & $\mathrm{ND}$ & $\mathrm{ND}$ & ND & $\mathrm{ND}$ & $\mathrm{ND}$ & $\mathrm{ND}$ & $\mathrm{ND}$ & $\mathrm{ND}$ \\
\hline $\mathrm{C}_{16: 0} 2-\mathrm{OH}$ & 1.9 & 1.6 & 2.9 & ND & ND & ND & ND & ND & ND & ND & ND \\
\hline $\mathrm{C}_{18: 1} \omega 7 c$ & 10.8 & 13.1 & 17.5 & 10.2 & 9.8 & 5.6 & 7.8 & 17.4 & 12.7 & 2.6 & 11.3 \\
\hline $\mathrm{C}_{18: 0}$ & 2.4 & 3.6 & 1.1 & 2.4 & 2.6 & 1.5 & 1.5 & $\operatorname{tr}$ & $\operatorname{tr}$ & 1.4 & $\operatorname{tr}$ \\
\hline
\end{tabular}

${ }^{\star}$ Strain $\mathrm{SC}-089^{\mathrm{T}}$ also contains $3.1 \%$ iso- $\mathrm{C}_{17: 0} 3-\mathrm{OH}$.

$\dagger$ Pigmentiphaga kullae LMG $21665^{\mathrm{T}}$ also contains $3.4 \% \mathrm{C}_{10: 0} 3-\mathrm{OH}$ and $2.4 \% \mathrm{C}_{18: 1} 2-\mathrm{OH}$.

$\ddagger$ Pusillimonas noertemanii DSM $10065^{\mathrm{T}}$ also contains $2.9 \% \mathrm{C}_{19: 0} 10$ methyl, $4.2 \% \mathrm{C}_{16: 0} 3-\mathrm{OH}$ and $5.8 \% \mathrm{C}_{18: 1} 2$ - $\mathrm{OH}$.

$\$$ Data from Kim et al. (2010).

IISF2, Summed feature $2\left(\mathrm{C}_{14: 0} 3-\mathrm{OH}\right.$ and/or iso- $\left.\mathrm{C}_{16: 1} \mathrm{I}\right)$.

- $\mathrm{SF} 3$, Summed feature $3\left(\mathrm{C}_{16: 1} \omega 7 c\right.$ and/or iso- $\left.\mathrm{C}_{15: 0} 2-\mathrm{OH}\right)$. 
Table 3. Qualitative comparison of the polar lipid profiles of different genera of the family Alcaligenaceae, according to criteria used by Stolz et al. (2005)

Genera: 1, Candidimonas gen. nov.; 2, Achromobacter; 3, Bordetella; 4, Castellaniella; 5, Pigmentiphaga; 6, Pusillimonas; 7, Parapusillimonas. PE, Phosphatidylethanolamine; PG, phosphatidylglycerol; DPG, diphosphatidylglycerol; APL and AL, respectively, unidentified aminophospholipid and aminolipid.

\begin{tabular}{|lccccccc|}
\hline Polar lipid & $\mathbf{1}$ & $\mathbf{2}$ & $\mathbf{3}$ & $\mathbf{4}$ & $\mathbf{5}$ & $\mathbf{6}$ & $\mathbf{7}$ \\
\hline PE & + & ++ & ++ & ++ & + & + & ++ \\
PG & + & ++ & ++ & ++ & + & + & + \\
DPG & + & + & ++ & ++ & \pm & + & ++ \\
APL1 & + & - & - & - & - & - & + \\
APL2 & + & - & - & - & - & - & - \\
APL3 & + & - & - & - & - & - & - \\
APL4 & + & - & - & - & - & - & - \\
APL5 & - & - & + & - & - & - & - \\
APL6 & - & - & + & - & - & - & - \\
AL1 & - & + & + & + & - & + & - \\
AL2 & - & + & - & - & - & ++ & - \\
& & & & & & & \\
\hline
\end{tabular}

et al., 1995, 1996; Weyant et al., 1995; Blümel et al., 2001; von Wintzingerode et al., 2001; Coenye et al., 2003; Busse \& Auling, 2005; Stolz et al., 2005; Kämpfer et al., 2006; Yoon et al., 2007; Liu et al., 2008; Chen et al., 2009; Kim et al., 2009, 2010; Lee et al., 2010; Srinivasan et al., 2010). In this respect, comparison of the type strains of the type species and of closely related species, as performed here and by Kim et al. (2010) in the description of the genus Parapusillimonas, allows an objective comparison of related taxa, useful for future identification or comparative assays. Due to the limitations mentioned above, some authors have supported the distinction of genera of the family Alcaligenaceae on the basis of phylogenetic or chemotaxonomic markers such as $16 \mathrm{~S}$ rRNA gene sequence signature nucleotides or the qualitative comparison of polar lipid patterns. Accordingly, strains $\mathrm{SC}-089^{\mathrm{T}}$ and $\mathrm{SC}-092^{\mathrm{T}}$ were compared with the type strains of their most closely related species and the type strains of type species of related genera on the basis of such criteria (Tables 3 and 4; Fig. 2). The two approaches allowed the distinction of these novel strains from related genera, supporting the proposal of a new genus.

Strains SC $-089^{\mathrm{T}}$ and $\mathrm{SC}-092^{\mathrm{T}}$ were observed to be phenotypically distinct, namely in their ability to reduce nitrate, grow anaerobically, oxidize glucose and assimilate some carbon sources (potassium 2-ketogluconate, 4hydroxybenzoic acid, trisodium citrate, malate and potassium gluconate). Additionally, the two strains differed in their cellular fatty acid profile and DNA G $+\mathrm{C}$ content. These differences, together with a $16 \mathrm{~S}$ rRNA gene sequence similarity of $99.1 \%$ and low level of DNA-DNA relatedness, suggest that strains SC $-089^{\mathrm{T}}$ and $\mathrm{SC}-092^{\mathrm{T}}$ represent two novel species of a new genus, for which we propose the names Candidimonas nitroreducens gen. nov., sp. nov. and Candidimonas humi sp. nov., respectively.

\section{Description of Candidimonas gen. nov.}

Candidimonas [Can.di.di.mo'nas. L. adj. candidus $-a-u m$ white; L. fem. n. monas a unit, monad; N.L. fem. n. Candidimonas a unit (rod) that produces white colonies].

Cells are non-spore-forming, Gram-negative, non-motile, curved short rods. Catalase- and cytochrome $c$ oxidasepositive. Mesophilic. Chemo-organotrophic with aerobic respiratory metabolism. Amino acids and organic acids are used as sole carbon sources. Anaerobic growth, nitrate reduction, glucose oxidation and the assimilation of some organic acids as sole carbon sources are variable characteristics of the genus. The respiratory quinone is ubiquinone 8 and the DNA G $+\mathrm{C}$ content is $64-65 \mathrm{~mol} \%$. Major fatty acids are summed feature $2\left(\mathrm{C}_{14: 0} 3-\mathrm{OH}\right.$ and/or iso- $\mathrm{C}_{16: 1}$ I), $\mathrm{C}_{16: 0}$ and $\mathrm{C}_{18: 1} \omega 7 c$. The polar lipids present are phosphatidylethanolamine, phosphatidylglycerol, diphosphatidylglycerol and four unidentified aminophospholipids. Phylogenetically, belongs to the family Alcaligenaceae. The type species is Candidimonas nitroreducens.

\section{Description of Candidimonas nitroreducens sp. nov.}

Candidimonas nitroreducens (ni.tro.re.du'cens. N.L. n. nitras -atis nitrate; N.L. pref. nitro- pertaining to nitrate; L. part. adj. reducens leading back, bringing back and, in chemistry, converting to a different oxidation state; N.L. part. adj. nitroreducens reducing nitrate).

Colonies are white, circular $(\sim 1 \mathrm{~mm}$ diameter $)$ and convex on PCA after $48 \mathrm{~h}$ incubation. Cells are coccobacilli $(0.53 \pm 0.11 \mu \mathrm{m})$. Growth occurs at $15-40{ }^{\circ} \mathrm{C}$, at $\mathrm{pH} 5-8$ and in the presence of up to $3 \%(\mathrm{w} / \mathrm{v}) \mathrm{NaCl}$ [optima at about $30{ }^{\circ} \mathrm{C}, \mathrm{pH} 7$ and $1 \%(\mathrm{w} / \mathrm{v}) \mathrm{NaCl}$. Under anaerobiosis, growth is slow and weak and nitrate is reduced to nitrite. Simmons citrate is not utilized. $\mathrm{H}_{2} \mathrm{~S}$, indole and acetoin are not produced. Aesculin is not hydrolysed. Glucose is oxidized (API 20E), but D-mannitol, inositol, Dsorbitol, L-rhamnose, sucrose, melibiose, amygdalin and Larabinose are not. Glucose is not fermented. Produces acid phosphatase, alkaline phosphatase, esterase (C4), esterase lipase (C8), leucine arylamidase, valine arylamidase and naphthol-AS-BI-phosphohydrolase, but not arginine dihydrolase, lysine decarboxylase, ornithine decarboxylase, tryptophan deaminase, gelatinase, urease, lipase (C14), cystine arylamidase, trypsin, $\alpha$-chymotrypsin, $\alpha$-galactosidase, $\beta$-galactosidase, $\beta$-glucuronidase, $\alpha$-glucosidase, $\beta$ glucosidase, $N$-acetyl- $\beta$-glucosaminidase, $\alpha$-mannosidase or $\alpha$-fucosidase. The following sole carbon sources are assimilated: adipate, phenyl acetate, itaconic acid, sodium acetate, lactic acid, 3-hydroxybenzoic acid, propionic acid, valeric acid, 3-hydroxybutyric acid and 4-hydroxybenzoic acid. Assimilation of malate and potassium gluconate is weak. The following sole carbon sources are not assimilated: 
Table 4. Pattern of $16 \mathrm{~S}$ rRNA signature nucleotides that distinguish different genera within the family Alcaligenaceae, selected as proposed by Blümel et al. (2001)

Genera: 1, Candidimonas gen. nov.; 2, Achromobacter; 3, Bordetella; 4, Castellaniella; 5, Pigmentiphaga; 6, Pusillimonas; 7, Parapusillimonas. Positions given are relative to Escherichia coli numbering and this analysis included the type strains of recognized species belonging to each of the indicated genera. Bold type indicates signature nucleotides different from those of the novel type strains, SC-089 ${ }^{\mathrm{T}}$ and SC-092 ${ }^{\mathrm{T}}$. GenBank accession numbers are as indicated in Fig. 1.

\begin{tabular}{|c|c|c|c|c|c|c|c|}
\hline Position & 1 & 2 & 3 & 4 & 5 & 6 & 7 \\
\hline $43: 399$ & $\mathrm{G}: \mathrm{C}$ & $\mathrm{G}: \mathrm{C}$ & $\mathrm{G}: \mathrm{C}$ & $\mathrm{G}: \mathrm{C}$ & $\mathrm{C}: \mathrm{G}$ & $\mathrm{G}: \mathrm{C}$ & G: C \\
\hline $82: 87$ & $C: G$ & $C: G$ & $C: G$ & G: C & $C: G$ & $\mathbf{A}: \mathbf{U}$ & $C: G$ \\
\hline 83 & $\mathrm{U}$ & $\mathrm{U}$ & $\mathrm{U}$ & C & $\mathrm{U}$ & $\mathrm{U}^{*}$ & $\mathrm{U}$ \\
\hline 85 & $\mathrm{C}$ & $\mathrm{C}$ & $\mathrm{C}$ & $\mathbf{U}$ & $\mathrm{C}$ & $\mathbf{G}^{*}$ & $\mathrm{C}$ \\
\hline $123: 238$ & $\mathrm{U}: \mathrm{A}$ & $\mathrm{U}: \mathrm{A}$ & $\mathrm{U}: \mathrm{A}$ & $\mathrm{U}: \mathrm{A}$ & $\mathrm{C}: \mathrm{G} \dagger$ & $\mathrm{U}: \mathrm{A}$ & $\mathrm{U}: \mathrm{A}$ \\
\hline $200: 217$ & $\mathrm{G}: \mathrm{C}$ & $A: U$ & $\mathrm{G}: \mathrm{C}$ & $\mathrm{G}: \mathrm{C}$ & $\mathrm{G}: \mathrm{C}$ & $\mathrm{G}: \mathrm{C}$ & $\mathrm{G}: \mathrm{C}$ \\
\hline $207: 212$ & $\mathrm{U}: \mathrm{A}$ & $\mathrm{U}: \mathrm{A}$ & $C: G$ & $\mathrm{U}: \mathrm{A}$ & $\mathrm{U}: \mathrm{A}$ & $C: G$ & $\mathrm{U}: \mathrm{A}$ \\
\hline 208 & G & G & $\mathbf{U}$ & G & G & $\mathrm{C}^{\star}$ & G \\
\hline 209 & $\mathrm{C}$ & $\mathrm{C}$ & $\mathbf{U}$ & $\mathrm{C}$ & $\mathrm{C}$ & $\mathrm{U}^{*}$ & $\mathrm{C}$ \\
\hline 210 & A & A & C & A & A & $\mathrm{U}^{*}$ & A \\
\hline 211 & A & A & G & A & A & $\mathrm{C}^{*}$ & A \\
\hline 412 & $\mathrm{U}$ & $\mathrm{U}$ & $\mathrm{U}$ & $\mathrm{U}$ & A & $\mathrm{U}$ & $\mathrm{U}$ \\
\hline $624: 616$ & $C: G$ & $\mathrm{U}: \mathrm{A} \ddagger$ & $C: G \S$ & $C: G \$$ & $C: G$ & $C: G^{*}$ & $C: G$ \\
\hline $673: 717$ & $A: U$ & $\mathrm{G}: \mathrm{C}$ & G: C & $\mathrm{A}: \mathrm{U}$ & G: C & $A: U$ & $A: U$ \\
\hline $1060: 1197$ & $\mathrm{U}: \mathrm{A}$ & $\mathrm{U}: \mathrm{A}$ & $\mathrm{U}: \mathrm{A}$ & $\mathrm{U}: \mathrm{A}$ & $C: G$ & $\mathrm{U}: \mathrm{A}$ & $\mathrm{U}: \mathrm{A}$ \\
\hline 1030 & C & C & $\mathrm{C}$ & C & A & C & C \\
\hline 1137 & A & A & A & G & A & A & A \\
\hline 1256 & $\mathrm{C}$ & $\mathbf{U}$ & UII & Uฯ & $\mathrm{C}$ & $\mathbf{U}$ & $\mathbf{U}$ \\
\hline 1283 & $\mathrm{C}$ & $\mathbf{U}$ & $\mathrm{C}$ & $\mathbf{U}$ & $\mathrm{C}$ & $\mathrm{U}^{*}$ & $\mathrm{C}$ \\
\hline 1308 & $\mathrm{C}$ & $\mathrm{C}$ & $\mathrm{C}$ & $\mathrm{C}$ & $\mathbf{U}$ & $\mathrm{U}$ & $\mathbf{U}$ \\
\hline 1329 & G & G & $\mathrm{G}$ & G & A & A & A \\
\hline
\end{tabular}

${ }^{\star}$ In Pusillimonas ginsengisoli, G is observed in positions 83 and 208, U in position 87, C in positions 209 and 1283 , A in positions 211 and 412 and the pair A: $U$ in position $624: 616$.

$\dagger$ In Pigmentiphaga litoralis, a U:A pair is observed in this position.

$\ddagger$ In A. insolitus, $\mathrm{C}: \mathrm{G}$ and A: $\mathrm{U}$ pairs are observed in positions $624: 616$ and $673: 717$, respectively.

$\$ I n$ B. avium, B. hinzii and C. defragrans, a U:A pair is observed.

IIC in B. petrii.

$\checkmark \mathrm{A}$ in C. caeni.

D-glucose, L-arabinose, D-mannose, D-mannitol, $N$-acetylglucosamine, maltose, citrate, L-rhamnose, D-ribose, inositol, sucrose, suberic acid, sodium malonate, L-alanine, potassium 5-ketogluconate, glycogen, L-serine, salicin, melibiose, Lfucose, D-sorbitol, capric acid, trisodium citrate, L-histidine, potassium 2-ketogluconate and L-proline. The predominant fatty acids are those listed in the genus description and $\mathrm{C}_{17}: 0$ cyclo.

The type strain, SC-089 ${ }^{\mathrm{T}}$ (=CCUG $55806^{\mathrm{T}}=\mathrm{LMG} 24812^{\mathrm{T}}$ ), was isolated from sewage sludge compost. The DNA G $+\mathrm{C}$ content of the type strain is $64 \mathrm{~mol} \%$.

\section{Description of Candidimonas humi sp. nov.}

Candidimonas humi (hu'mi. L. n. humus earth, soil and, in earth sciences or agriculture, humus; L. gen. n. humi of the soil, of the humus).
Colonies are white, circular $(\sim 1 \mathrm{~mm}$ diameter $)$, convex and rough on PCA after $48 \mathrm{~h}$ incubation. Cells are coccobacilli $(0.50 \pm 0.09 \mu \mathrm{m})$. Growth occurs at $15-40{ }^{\circ} \mathrm{C}$, at $\mathrm{pH} 5-8$ and in the presence of up to $3 \%(\mathrm{w} / \mathrm{v}) \mathrm{NaCl}$ [optima about $30{ }^{\circ} \mathrm{C}$, pH 7 and $1 \%(\mathrm{w} / \mathrm{v}) \mathrm{NaCl}$. Unable to grow under anaerobiosis or to reduce nitrate. Simmons citrate is not utilized. $\mathrm{H}_{2} \mathrm{~S}$, indole and acetoin are not produced. Aesculin is not hydrolysed. Glucose is not fermented. Produces acid phosphatase, alkaline phosphatase, esterase (C4), esterase lipase (C8), leucine arylamidase, valine arylamidase, naphthol-AS-BI-phosphohydrolase and $\alpha$ chymotrypsin, but not arginine dihydrolase, lysine decarboxylase, ornithine decarboxylase, tryptophan deaminase, gelatinase, urease, lipase (C14), cystine arylamidase, trypsin, $\alpha$ galactosidase, $\beta$-galactosidase, $\beta$-glucuronidase, $\alpha$-glucosidase, $\beta$-glucosidase, $N$-acetyl- $\beta$-glucosaminidase, $\alpha$-mannosidase or $\alpha$-fucosidase. The following sole carbon sources are assimilated: adipate, citrate, phenyl acetate, itaconic acid, sodium acetate, 
lactic acid, 3-hydroxybenzoic acid, propionic acid, valeric acid, trisodium citrate, potassium 2-ketogluconate and 3-hydroxybutyric acid. The carbon sources D-glucose, L-arabinose, Dmannose, D-mannitol, $\mathrm{N}$-acetylglucosamine, maltose, malate, potassium gluconate, L-rhamnose, D-ribose, inositol, sucrose, suberic acid, sodium malonate, L-alanine, potassium 5ketogluconate, glycogen, L-serine, salicin, melibiose, L-fucose, D-sorbitol, capric acid, L-histidine, 4-hydroxybenzoic acid and L-proline are not assimilated. The predominant fatty acids are those listed in the genus description and summed feature 3 $\left(\mathrm{C}_{16: 1} \omega 7 c\right.$ or iso- $\mathrm{C}_{15: 0} 2-\mathrm{OH}$ or both $)$.

The type strain, SC $-092^{\mathrm{T}}\left(=\right.$ CCUG $\left.55807^{\mathrm{T}}=\mathrm{LMG} 24813^{\mathrm{T}}\right)$, was isolated from sewage sludge compost. The DNA G + C content of the type strain is $65 \mathrm{~mol} \%$.

\section{Acknowledgements}

The authors acknowledge the expertise of K. Molin and Professor Enevold Falsen (CCUG) for their technical and scientific assistance.

\section{References}

Blümel, S., Mark, B., Busse, H.-J., Kämpfer, P. \& Stolz, A. (2001). Pigmentiphaga kullae gen. nov., sp. nov., a novel member of the family Alcaligenaceae with the ability to decolorize azo dyes aerobically. Int $J$ Syst Evol Microbiol 51, 1867-1871.

Busse, H.-J. \& Auling, G. (2005). Family III. Alcaligenaceae De Ley, Segers, Kersters, Mannheim and Lievens $1986,412^{\mathrm{VP}}$. In Bergey's Manual of Systematic Bacteriology, vol. 2, pp. 647-685. Edited by D. J. Brenner, N. R. Krieg \& J. T. Stanley. New York: Springer.

Chen, Y.-G., Zhang, Y.-Q., Huang, K., Tang, S.-K., Cao, Y., Shi, J.-X., Xiao, H.-D., Cui, X.-L. \& Li, W.-J. (2009). Pigmentiphaga litoralis sp. nov., a facultatively anaerobic bacterium isolated from a tidal flat sediment. Int J Syst Evol Microbiol 59, 521-525.

Coenye, T., Vancanneyt, M., Falsen, E., Swings, J. \& Vandamme, P. (2003). Achromobacter insolitus sp. nov. and Achromobacter spanius sp. nov., from human clinical samples. Int J Syst Evol Microbiol 53, 1819-1824.

Ezaki, T., Hashimoto, Y. \& Yabuuchi, E. (1989). Fluorometric deoxyribonucleic acid-deoxyribonucleic acid hybridization in microdilution wells as an alternative to membrane-filter hybridization in which radioisotopes are used to determine genetic relatedness among bacterial strains. Int J Syst Bacteriol 39, 224-229.

Ferreira da Silva, M., Vaz-Moreira, I., Gonzalez-Pajuelo, M., Nunes, O. C. \& Manaia, C. M. (2007). Antimicrobial resistance patterns in Enterobacteriaceae isolated from an urban wastewater treatment plant. FEMS Microbiol Ecol 60, 166-176.

Foss, S., Heyen, U. \& Harder, J. (1998). Alcaligenes defragrans sp. nov., description of four strains isolated on alkenoic monoterpenes $((+)$-menthene, $\alpha$-pinene, 2 -carene, and $\alpha$-phellandrene) and nitrate. Syst Appl Microbiol 21, 237-244.

Jukes, T. H. \& Cantor, C. R. (1969). Evolution of protein molecules. In Mammalian Protein Metabolism, vol. 3, pp. 21-132. Edited by H. N. Munro. New York: Academic Press.

Kämpfer, P., Denger, K., Cook, A. M., Lee, S.-T., Jäckel, U., Denner, E. B. M. \& Busse, H.-J. (2006). Castellaniella gen. nov., to accommodate the phylogenetic lineage of Alcaligenes defragrans, and proposal of Castellaniella defragrans gen. nov., comb. nov. and Castellaniella denitrificans sp. nov. Int J Syst Evol Microbiol 56, 815-819.
Kersters, K., Hinz, K.-H., Hertle, A., Segers, P., Lievens, A., Siegmann, O. \& De Ley, J. (1984). Bordetella avium sp. nov., isolated from the respiratory tracts of turkeys and other birds. Int $J$ Syst Bacteriol 34, 56-70.

Kim, M. K., Srinivasan, S., Kim, Y. J. \& Yang, D. C. (2009). Castellaniella ginsengisoli sp. nov., a $\beta$-glucosidase-producing bacterium. Int J Syst Evol Microbiol 59, 2191-2194.

Kim, Y.-J., Kim, M. K., Im, W. T., Srinivasan, S. \& Yang, D.-C. (2010). Parapusillimonas granuli gen. nov., sp. nov., isolated from granules from a wastewater-treatment bioreactor. Int J Syst Evol Microbiol 60, 14011406.

Lee, M., Jung, H. M., Woo, S. G., Yoo, S. A. \& Ten, L. N. (2010). Castellaniella daejeonensis sp. nov., isolated from soil. Int J Syst Evol Microbiol 60, 2056-2060.

Liu, Q. M., Ten, L. N., Im, W. T. \& Lee, S. T. (2008). Castellaniella caeni sp. nov., a denitrifying bacterium isolated from sludge of a leachate treatment plant. Int J Syst Evol Microbiol 58, 2141-2146.

Manaia, C. M., Nogales, B., Weiss, N. \& Nunes, O. C. (2004). Gulosibacter molinativorax gen. nov., sp. nov., a molinate-degrading bacterium, and classification of 'Brevibacterium helvolum' DSM 20419 as Pseudoclavibacter helvolus gen. nov., sp. nov. Int J Syst Evol Microbiol 54, 783-789.

Mesbah, M., Premachandran, U. \& Whitman, W. B. (1989). Precise measurement of the $\mathrm{G}+\mathrm{C}$ content of deoxyribonucleic acid by highperformance liquid chromatography. Int J Syst Bacteriol 39, 159-167.

Murray, R. G. E., Doetsch, R. N. \& Robinow, F. (1994). Determinative and cytological light microscopy. In Methods for General and Molecular Bacteriology, pp. 21-41. Edited by P. Gerhardt, R. G. E. Murray, W. A. Wood \& N. R. Krieg. Washington, DC: American Society for Microbiology.

Pitcher, D. G., Saunders, N. A. \& Owen, R. J. (1989). Rapid extraction of bacterial genomic DNA with guanidium thiocyanate. Lett Appl Microbiol 8, 151-156.

Sanden, G. N. \& Weyant, R. S. (2005). Genus III. Bordetella Moreno-López $1952,178^{\mathrm{AL}}$. In Bergey's Manual of Systematic Bacteriology, vol. 2, pp. 662671. Edited by D. J. Brenner, N. R. Krieg \& J. T. Stanley. New York: Springer.

Smibert, R. M. \& Krieg, N. R. (1994). Phenotypic characterization. In Methods for General and Molecular Bacteriology, pp. 607-654. Edited by P. Gerhardt, R. G. E. Murray, W. A. Wood \& N. R. Krieg. Washington, DC: American Society for Microbiology.

Srinivasan, S., Kim, M. K., Sathiyaraj, G., Kim, Y. J. \& Yang, D. C. (2010). Pusillimonas ginsengisoli sp. nov., isolated from soil of a ginseng field. Int J Syst Evol Microbiol 60, 1783-1787.

Stolz, A., Bürger, S., Kuhm, A., Kämpfer, P. \& Busse, H.-J. (2005). Pusillimonas noertemannii gen. nov., sp. nov., a new member of the family Alcaligenaceae that degrades substituted salicylates. Int J Syst Evol Microbiol 55, 1077-1081.

Tindall, B. J. (1989). Fully saturated menaquinones in the archaebacterium Pyrobaculum islandicum. FEMS Microbiol Lett 60, 251-254.

Vancanneyt, M., Vandamme, P. \& Kersters, K. (1995). Differentiation of Bordetella pertussis, B. parapertussis and B. bronchiseptica by wholecell protein electrophoresis and fatty acid analysis. Int J Syst Bacteriol 45, 843-847.

Vandamme, P., Vancanneyt, M., Pot, B., Mels, L., Hoste, B., Dewettinck, D., Vlaes, L., van den Borre, C., Higgins, R. \& other authors (1992). Polyphasic taxonomic study of the emended genus Arcobacter with Arcobacter butzleri comb. nov. and Arcobacter skirrowii sp. nov., an aerotolerant bacterium isolated from veterinary specimens. Int J Syst Bacteriol 42, 344-356.

Vandamme, P., Hommez, J., Vancanneyt, M., Monsieurs, M., Hoste, B., Cookson, B., Wirsing von König, C. H., Kersters, K. \& Blackall, P. J. 
(1995). Bordetella hinzii sp. nov., isolated from poultry and humans. Int J Syst Bacteriol 45, 37-45.

Vandamme, P., Heyndrickx, M., Vancanneyt, M., Hoste, B., De Vos, P., Falsen, E., Kersters, K. \& Hinz, K. H. (1996). Bordetella trematum sp. nov., isolated from wounds and ear infections in humans, and reassessment of Alcaligenes denitrificans Rüger and Tan 1983. Int J Syst Bacteriol 46, 849-858.

Vaz-Moreira, I., Nobre, M. F., Nunes, O. C. \& Manaia, C. M. (2007). Gulbenkiania mobilis gen. nov., sp. nov., isolated from treated municipal wastewater. Int J Syst Evol Microbiol 57, 1108-1112.

Vaz-Moreira, I., Silva, M. E., Manaia, C. M. \& Nunes, O. C. (2008). Diversity of bacterial isolates from commercial and homemade composts. Microb Ecol 55, 714-722. von Wintzingerode, F., Schattke, A., Siddiqui, R. A., Rösick, U., Göbel, U. B. \& Gross, R. (2001). Bordetella petrii sp. nov., isolated from an anaerobic bioreactor, and emended description of the genus Bordetella. Int J Syst Evol Microbiol 51, 1257-1265.

Weyant, R. S., Hollis, D. G., Weaver, R. E., Amin, M. F. M., Steigerwalt, A. G., O'Connor, S. P., Whitney, A. M., Daneshvar, M. I., Moss, C. W. \& Brenner, D. J. (1995). Bordetella holmesii sp. nov., a new gramnegative species associated with septicemia. J Clin Microbiol 33, $1-7$.

Yoon, J. H., Kang, S. J., Kim, W. \& Oh, T. K. (2007). Pigmentiphaga daeguensis sp. nov., isolated from wastewater of a dye works, and emended description of the genus Pigmentiphaga. Int J Syst Evol Microbiol 57, 1188-1191. 